\title{
Assessment of the bacterial community structure in shallow and deep sediments of the Perdido Fold Belt region in the Gulf of Mexico
}

\author{
Ma. Fernanda Sánchez-Soto Jiménez ${ }^{1}$ ， Daniel Cerqueda-García ${ }^{2}$ ， Jorge L. Montero-Muñoz ${ }^{1}$ ， Ma. Leopoldina

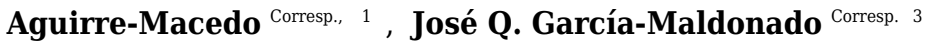 \\ ${ }^{1}$ Centro de Investigación y de Estudios Avanzados del Instituto Politécnico Nacional, Unidad Mérida. Departamento de Recursos del Mar, Mérida, Yucatán, \\ México \\ ${ }^{2}$ Consorcio de Investigación del Golfo de México (CIGOM). Centro de Investigación y de Estudios Avanzados del Instituto Politécnico Nacional, Unidad \\ Mérida. Departamento de Recursos del Mar, Mérida, Yucatán, México \\ 3 CONACYT - Centro de Investigación y de Estudios Avanzados del Instituto Politécnico Nacional, Unidad Mérida. Departamento de Recursos del Mar, \\ Mérida, Yucatán, México \\ Corresponding Authors: Ma. Leopoldina Aguirre-Macedo, José Q. García-Maldonado \\ Email address: leopoldina.aguirre@cinvestav.mx, jose.garcia@cinvestav.mx
}

The Mexican region of the Perdido Fold Belt (PFB), in northwestern Gulf of Mexico (GoM), is a geological province with important oil reservoirs that will be subjected to forthcoming oil exploration and extraction activities. To date, little is known about the native microbial communities of this region, and how these change relative to water depth. In this study we assessed the bacterial community structure of surficial sediments by high-throughput sequencing of the 16S rRNA gene at 11 sites in the PFB, along a water column depth gradient from 20 to $3700 \mathrm{~m}$, including 5 shallow $(20-600 \mathrm{~m})$ and 6 deep (2800-3700 m) samples. The results indicated that OTUs richness and diversity were higher for shallow sites (OTUs $=2888.2 \pm 567.88 ; H^{\prime}=9.6 \pm 0.85$ ) than for deep sites (OTUs $=1884.7 \pm$ $464.2 ; H^{\prime}=7.74 \pm 1.02$ ). Nonmetric multidimensional scaling (NMDS) ordination revealed that shallow microbial communities grouped separately from deep samples. Additionally, the shallow sites plotted further from each other on the NMDS whereas samples from the deeper sites (abyssal plains) plotted much more closely to each other. These differences were related to depth, redox potential, sulfur concentration, and grain size (lime and clay), based on the environmental variables fitted with the axis of the NMDS ordination. In addition, differential abundance analysis identified 147 OTUs with significant fold changes among the zones (107 from shallow and 40 from deep sites), which constituted 10 to $40 \%$ of the total relative abundances of the microbial communities. The most abundant OTUs with significant fold changes in shallow samples corresponded to Kordiimonadales, Rhodospirillales, Desulfobacterales (Desulfococcus), Syntrophobacterales and Nitrospirales (GOUTA 19, BD2-6, LCP-6), whilst Chromatiales, Oceanospirillales (Amphritea, Alcanivorax), Methylococcales, Flavobacteriales, Alteromonadales (Shewanella, ZD0117) 
and Rhodobacterales were the better represented taxa in deep samples. Several of the OTUs detected in both deep and shallow sites have been previously related to hydrocarbons consumption. Thus, this metabolism seems to be well represented in the studied sites, and it could abate future hydrocarbon contamination in this ecosystem. The results presented herein, along with biological and physicochemical data, constitute an available reference for further monitoring of the bacterial communities in this economically important region in the GoM. 
1 Assessment of the bacterial community structure in shallow and deep sediments of the

2 Perdido Fold Belt region in the Gulf of Mexico

3

4

5

6

7

8

9

10

11

12

13

14

15

16

17

\author{
Ma. Fernanda Sánchez-Soto Jiménez ${ }^{1}$, Daniel Cerqueda-García², Jorge L. Montero-Muñoz ${ }^{1}$, Ma. \\ Leopoldina Aguirre-Macedo ${ }^{1 *}$ and José Q. García-Maldonado ${ }^{*}$ \\ Ma. Fernanda Sánchez-Soto Jiménez ${ }^{1}$, maria.sanchez-soto@,cinvestav.mx \\ Daniel Cerqueda-García ${ }^{2}$, dacegabiol@ciencias.unam.mx \\ Jorge L. Montero-Muñoz ${ }^{1}$, jorge.montero@cinvestav.mx \\ Ma. Leopoldina Aguirre-Macedo ${ }^{1^{*}}$, leopoldina.aguirre@cinvestav.mx (corresponding author) \\ José Q. García-Maldonado ${ }^{3 *}$, jose.garcia@cinvestav.mx (corresponding author) \\ ${ }^{1}$ Centro de Investigación y de Estudios Avanzados del Instituto Politécnico Nacional, Unidad \\ Mérida. Departamento de Recursos del Mar. Mérida, Yucatán, México. \\ ${ }^{2}$ Consorcio de Investigación del Golfo de México (CIGOM). Centro de Investigación y de \\ Estudios Avanzados del Instituto Politécnico Nacional,Unidad Mérida. Departamento de \\ Recursos del Mar. Mérida, Yucatán, México. \\ ${ }^{3}$ CONACYT - Centro de Investigación y de Estudios Avanzados del Instituto Politécnico \\ Nacional, Unidad Mérida. Departamento de Recursos del Mar. Mérida, Yucatán, México.
}

\title{
Abstract
}

The Mexican region of the Perdido Fold Belt (PFB), in northwestern Gulf of Mexico (GoM), is a geological province with important oil reservoirs that will be subjected to forthcoming oil exploration and extraction activities. To date, little is known about the native microbial communities of this region, and how these change relative to water depth. In this study we assessed the bacterial community structure of surficial sediments by high-throughput sequencing of the $16 \mathrm{~S}$ rRNA gene at 11 sites in the PFB, along a water column depth gradient from 20 to $3700 \mathrm{~m}$, including 5 shallow $(20-600 \mathrm{~m})$ and 6 deep (2800-3700 m) samples. The results indicated that OTUs richness and diversity were higher for shallow sites (OTUs $=2888.2 \pm$ $\left.567.88 ; H^{\prime}=9.6 \pm 0.85\right)$ than for deep sites (OTUs $\left.=1884.7 \pm 464.2 ; H^{\prime}=7.74 \pm 1.02\right)$.

Nonmetric multidimensional scaling (NMDS) ordination revealed that shallow microbial communities grouped separately from deep samples. Additionally, the shallow sites plotted 
33 further from each other on the NMDS whereas samples from the deeper sites (abyssal plains)

34 plotted much more closely to each other. These differences were related to depth, redox

35 potential, sulfur concentration, and grain size (lime and clay), based on the environmental

36 variables fitted with the axis of the NMDS ordination. In addition, differential abundance

37 analysis identified 147 OTUs with significant fold changes among the zones (107 from shallow

38 and 40 from deep sites), which constituted 10 to $40 \%$ of the total relative abundances of the

39 microbial communities. The most abundant OTUs with significant fold changes in shallow

40 samples corresponded to Kordiimonadales, Rhodospirillales, Desulfobacterales (Desulfococcus),

41 Syntrophobacterales and Nitrospirales (GOUTA 19, BD2-6, LCP-6), whilst Chromatiales,

42 Oceanospirillales (Amphritea, Alcanivorax), Methylococcales, Flavobacteriales,

43 Alteromonadales (Shewanella, ZD0117) and Rhodobacterales were the better represented taxa in

44 deep samples. Several of the OTUs detected in both deep and shallow sites have been previously

45 related to hydrocarbons consumption. Thus, this metabolism seems to be well represented in the

46 studied sites, and it could abate future hydrocarbon contamination in this ecosystem. The results

47 presented herein, along with biological and physicochemical data, constitute an available

48 reference for further monitoring of the bacterial communities in this economically important

49 region in the GoM.

50

\section{Introduction}

Microorganisms are well recognized as key drivers of biogeochemical cycles in marine

53 environments (Webster et al. 2003; Santos et al. 2011). Measuring the changes in microbial

54 communities is of particular interest to understanding how environmental factors modulate their

55 structure and how that, in turn, is related to the function and stability of the ecosystem (Huber et 
56 al. 2007; Jones et al. 2012; Fuhrman et al. 2015). In marine sediments, the type of substrate,

57 energy and carbon sources, and the variables that are correlated with water depth (e.g.,

58 temperature, oxygen concentration, light penetration and hydrostatic pressure), generally

59 describe the most important aspects of the variability amongst habitats (Miller et al. 2012).

60 In the Gulf of Mexico (GoM), changes in bacterial community structure have been mainly

61 related with depth in the water column, and likely result from differences in temperature,

62 dissolved oxygen and suspended particles (King et al. 2013) which occur across these depth

63 differences. In marine sediments from the GoM, bacterial community composition has been

64 determined at different depths below the seafloor (from sediment cores). It has been proposed

65 that the bacterial community composition of these sediments likely results from the interaction

66 between the water column and a benthic microbial population limited to the upper layer of the

67 sediments (Reese et al. 2013). In contrast, the microbial diversity present in different sediment

68 depths from seep systems in the GoM have been directly related to the composition and

69 magnitude of hydrocarbon seepage (e.g., natural oils, methane, and non-methane hydrocarbons)

70 (Orcutt et al. 2010), as well as to the presence of overlying microbial mats (Mills et al. 2004).

72 Knowledge about microbial communities in the GoM increased notably with the Deepwater

73 Horizon (DWH) massive oil spill in 2010, which occurred in the north zone of the GoM across

74 an enormous area with different environmental conditions (Kostka et al 2011; Mason et al. 2012;

75 Liu and Liu 2013; Joye et al. 2014). During the spill, it was observed that different bacterial

76 phyla in the deep-water plume (e.g., Oceanospirillales, Cycloclasticus and Colwellia) rapidly

77 responded and were enriched within hours - weeks following the DWH well blow out (Redmond

78 and Valentine 2011; Mason et al. 2012). In natural hydrocarbon seep sites sampled at the same 
79 time, several rare taxa increased rapidly in abundance after the spill, emphasizing the importance

80 of specialized sub-populations and potential ecotypes during massive deep-sea oil discharges

81 (Kleindienst et al. 2015). The oil transported to the shoreline after the discharge also had a

82 profound impact on the abundance and community composition of indigenous bacteria in beach

83 sands, where members of the Gammaproteobacteria and Alphaproteobacteria participated as

84 key players in oil degradation (Kostka et al. 2011).

85

86 The precise volume of oil spilled and the trajectory of the oil slicks from the DHW are still

87 controversial (Salcedo et al. 2017). Based on the surface circulation models of the waters of the

88 GoM, it was inferred that the Mexican region of the Perdido Fold Belt (PFB), was also

89 susceptible to this environmental disturbance (Soto and Vázquez-Botello 2013). Knowledge of

90 environmental and biotic data of this region is, however, scarce despite being a geologic

91 province with oil reservoirs. The present study assessed changes in the bacterial community

92 structure of surficial sediments with respect to a depth gradient and specific environmental

93 variables in the PFB region, where oil exploration and extraction activities are predicted to

94 impact environmental conditions, and consequently the structure of bacterial communities.

95 Additionally, bacterial phylotypes putatively involved in hydrocarbon degradation were

96 highlighted in this work.

97

98 Material and Methods

99 Sample collection and physicochemical variables from marine sediments

100 The samples used in this study were collected in the Northwestern Gulf of Mexico in April 2014.

101 Sediment samples from a depth gradient $(20-3700 \mathrm{~m})$, were collected perpendicular to the 
102 coastline at 11 sites on the parallels 25 and $25.15^{\circ} \mathrm{N}$ (Fig. 1, Table 1). Samples were collected

103 with a Hessler-Sandia MK-II boxcore $(40$ x $40 \mathrm{~cm})$ from which three different surficial $(0$ - 5

$104 \mathrm{~cm}$ ) subsamples were taken: 1) sterile $100 \mathrm{~mL}$ plastic containers immediately frozen at $-20^{\circ} \mathrm{C}$ on

105 board for further molecular analysis; 2) a 2 inch core extracted to determine total sulfur

106 concentration (TS) and redox potential on board, with a sulfide ion selective electrode and

107 potentiometer (Bricker 1982; Brassard 1997); and 3) approximately $400 \mathrm{~g}$ of sediment stored in

108 high density polyethylene bags at $4^{\circ} \mathrm{C}$ until the determination of total organic matter (TOM),

109 total organic carbon (TOC), and grain size in the laboratory. TOM was determined by the wet

110 oxidation technique with an excess of dichromate and back titration with iron (II) (Buchanan,

111 1984), TOC content was quantified using the oxidation with potassium dichromate in acid

112 medium, and titration of excess oxidant with ferrous sulfate and diphenylamine as an indicator

113 (Buchanan 1984). The amounts of sand, lime and clay were estimated using a hydrometer

114 (Buchanan 1984). These physicochemical variables were compared among shallow and deep

115 sites using a one-way analysis of variance (ANOVA $p<0.05$ and $F$-values) and were correlated

116 with the depth variable.

\section{DNA extraction}

118 Sediment samples were stored during five months at $-20^{\circ} \mathrm{C}$. Then, in October 2014 sediments

119 were thawed at $4^{\circ} \mathrm{C}$, homogenized mechanically under sterile conditions, and centrifuged 1

$120 \mathrm{~min} / 10,000 \mathrm{x} \mathrm{g}$ in order to separate the sediment from remaining water, which was discarded.

121 Total DNA was extracted from $0.25 \mathrm{~g}$ of sediment using the PowerSoiløDNA Isolation Kit (Mo

122 Bio Laboratories, Carlsbad, CA, USA) following the manufacturer's protocol. The quality of the 123 DNA extractions was verified by agarose gel electrophoresis and the concentration was

124 determined through UV absorption analysis with a NanoDrop 2000 Spectrometer (ThermoFisher 
125 Scientific Inc., Wilmington, DE, USA). Extracted DNA was stored at $-20^{\circ} \mathrm{C}$ for further $16 \mathrm{~S}$

126 rRNA Illumina sequencing and DGGE analysis (see a detailed description in supplementary

127 methods).

\section{16S rRNA gene sequencing}

129 Amplicons from environmental DNA were prepared for sequencing the 16S rRNA V3 and V4

130 variable regions by using a two PCR steps approach following the "16S Metagenomic

131 Sequencing Library Preparation" protocol (Illumina). Briefly, the first PCR step amplified the

132 template out of the DNA samples using the forward primer 5'-CCTACGGGNGGCWGCAG-3'

133 and the reverse primer 5'-GACTACHVGGGTATCTAATCC-3' with Illumina overhang

134 adapters attached, to obtain $\sim 550$ bp fragments (Klindworth et al. 2013). The PCR program was

135 performed in a thermal cycler (Applied Biosystems Veriti ABI Inc., Foster City, CA, USA) with

136 an initial denaturation at $95^{\circ} \mathrm{C}-3 \mathrm{~min}, 25$ cycles of $95^{\circ} \mathrm{C}-30 \mathrm{~s}, 55^{\circ} \mathrm{C}-30 \mathrm{~s}, 72^{\circ} \mathrm{C}-30 \mathrm{~s}$ and a

137 final extension at $72^{\circ} \mathrm{C}-5 \mathrm{~min}$. Each PCR reaction $(20 \mu \mathrm{l})$ included $2 \mu \mathrm{l}$ of environmental DNA

$138(5 \mathrm{ng} / \mu \mathrm{l}), 0.5 \mu \mathrm{l}$ of each primer $(10 \mu \mathrm{M})$ and $10 \mu \mathrm{l}$ of $2 \mathrm{x}$ Phusion High-Fidelity MasterMix

139 (Thermo Scientific, Waltham, MA, USA). The correct size of the amplicons was verified on an

140 QIAxcel Advanced system (QIAGEN, Hilden, Germany), DNA and the PCR clean-up were

141 carried out using AMPure XP beads to discard free primers and primer dimer species. In the

142 second PCR, eight cycles attached dual indices and the Illumina sequencing adapters using the

143 Nextera XT Index Kit. PCR barcoded amplicons were verified and purified as previously

144 described and quantified using a Qubit 3.0 fluorometer (Life Technology, Shah Alam, Selangor,

145 Malaysia). The individual barcoded amplicons were diluted on $10 \mathrm{mM}$ Tris ( $\mathrm{pH} \mathrm{8.5)} \mathrm{and} \mathrm{pooled}$

146 in equimolar concentrations (9 pM). Paired-end sequencing ( $2 \times 300 \mathrm{bp})$ was carried out using the 
147 MiSeq platform (Illumina, San Diego, CA, USA) with a MiSeq Reagent Kit V3 (600 cycles).

148 Sequencing was performed in the Aquatic Pathology laboratory at CINVESTAV-Mérida.

\section{Data analysis}

150 Demultiplexing of the pooled amplicons and trimming the barcode and adapter sequences was

151 performed using the MiSeq Reporter Metagenomics Workflow (Illumina, 2014). Reads were

152 overlapped with the fast length adjustment of short reads to improve genome assemblies

153 (FLASH) software (Magoč and Salzberg, 2011), and processed using the QIIME (version 1.9)

154 (Caporaso et al., 2010) pipeline with the parameters q (phred_quality_treshold) $=20, \mathrm{r}$

155 (max_bad_run_length, $)=3, \mathrm{p}$ (min_per_read_length_fraction $)=0.75$, for quality filtering. The

156 demultiplexed sequences were clustered in operational taxonomic units (OTUs) with the

157 'pick_open_reference_otus.py' script at 97\% of similarity using the usearch61 method (Edgar

158 2010) with a minimum OTU cluster size of 5. Chimeric sequences were removed with the

159 uchime2 algorithm in the reference mode (v 9.1.13) (Edgar 2016) and, the taxonomic assignment

160 was performed by the SortMeRna (Kopylova et al. 2012) with an $e$-value of $3 e^{-6}$ and default

161 parameters from QIIME, using the GreenGenes database (v13.8). An OTUs alignment was

162 performed with the Mafft algorithm (Katoh and Standley 2013) to build a phylogenetic tree using

163 the Fasttree software (Price et al. 2009) for its subsequent use in the UniFrac (Lozupone,

164 Hamady and Knight, 2006) distance analysis.

165 Community structure and composition analyses were performed by processing the OTU table in

166 the R environment (R Core Team, 2014) with the Phyloseq (McMurdie and Holmes 2013),

167 vegan (Oksanen et al. 2013) and ggplot2 (Wickham, 2010) packages. The data set was rarefied at

168 the depth from the smallest library $(20,400)$. We reported the observed OTUs, the Shannon and 
169 Simpson diversity indexes ( $H^{\prime}$ and $D$, respectively) and the nonparametric richness from Chaol.

170 The Good's coverage was calculated to corroborate the adequate sampling depth.

171 In order to compare the microbial community composition among shallow and deep sampling

172 sites, a non-metric multidimensional scaling (NMDS) was plotted (Lozupone et al. 2006;

173 Giloteaux et al. 2010) with the weighted UniFrac distance metric (Lozupone, Hamady and

174 Knight, 2006) and a test of beta significance among groups of sample was performed using a

175 two-sided Student's two-sample t-test with the 'make_distance_boxplots.py' script of QIIME, $p$ -

176 values were calculated using 1000 Monte Carlo permutations. The physicochemical variables

177 were fitted with the envfit function to the NMDS ordination to correlate them with the

178 community composition ( $p$-value $<0.05$ and 10000 permutations). Physicochemical variables

179 were also tested with a PERMANOVA analysis at a $p$-value $<0.05$ (Table S1). A differential

180 abundance analysis was performed with the DESeq2 (Love et al, 2014) R library to identify the

181 OTUs that have significant fold changes among the shallow and deep zones. The $p$-value was

182 corrected with the false discovery rate (FDR) method (Benjamini and Hochberg, 1995) and a

183 Log2 fold change plot was made with the significant OTUs at a $p$-value $<0.01$.

184 All the sequences are available at SRA site from NCBI database in the BioProject

185 PRJNA429278 and biosample accession ID's SRR6457706 to SRR6457716 and the raw

186 processed data in the supplementary material.

188 Results

189 Physicochemical properties from marine sediments 
190 The physicochemical variables and textures of the sediment samples are shown in Table 1.

191 Redox potential ranged from -204 to $236 \mathrm{mV}$. The electronegative values were found in samples

192 from 20 to $600 \mathrm{~m}$ depth, while the electropositive values corresponded to the deep sediments

193 (2800-3700 m). TS was constant at depths from 20 to $600 \mathrm{~m}$ at a concentration of $0.05 \mu \mathrm{M}$,

194 while the maximum values were detected for deep sites $(0.10-0.12 \mu \mathrm{M})$. The percentage of

195 TOM and the concentration of TOC varied for all sites with averages of $0.872 \pm 0.22 \%$ and

$1960.484 \pm 0.123 \mu \mathrm{M}$, respectively. The percentages of sand, lime and clay in the sediment samples

197 ranged from 20.50 - 34.5, 51.2 - 70.30 and $5.9-28.4 \%$, respectively. Values of TS, redox

198 potential, and the percentages of lime and clay showed significant correlations with depth $(p$ -

199 value $<0.01)$ (Table 1).

200

201 Bacterial community structure in a depth gradient

202 The NMDS ordination method showed that microbial communities from shallow sites grouped

203 separately from those from the deep sites (Fig. 2), and it was according with the test of

204 significance were the mean of the distances of Shallow and Deep samples were different with a

$205 p$-value $<0.05$. Samples taken from shallow sites displayed greater dissimilarity distance from

206 each other, while those derived from the deep sites displayed a closer proximity to each other

207 (Fig. 2). The environmental variables fitted on the NMDS ordination were: depth $(r=0.79)$,

208 redox potential $\left(r^{2}=0.77\right)$, the concentration of total sulfur $\left(r^{2}=0.73\right)$ and percentages of clay $\left(r^{2}=\right.$

$2090.71)$ and lime $\left(r^{2}=0.7\right)$, at a $p$-value $<0.05$.

210 The observed OTUs, Shannon $\left(H^{\prime}\right)$ and Simpson $(D)$ diversity indexes, and the nonparametric

211 richness estimation from Chaol, were different among shallow and deep-sea sites ( $p$-value 
$212<0.05)$. These ecological estimators showed higher values in the sediment samples from shallow

213 sites (observed OTUs $=2888.2 \pm 567.88, H^{\prime}=9.6 \pm 0.85, D=0.99 \pm 0.005$ and Chaol $=3791.2$

$214 \pm 737.81)$ than those obtained from the deep ocean floor (observed OTUs $=1884.7 \pm 464.2, H^{\prime}=$

$2157.74 \pm 1.02, D=0.97 \pm 0.02$, and Chaol $=2806.18 \pm 589.39)($ Table 2).

216

217

218

219

220

221

222

223

224

225

226

227

228

229

230

231

232

233

\section{Bacterial community composition}

Microbial community analysis resulted in the detection of 25 bacterial phyla, however only 14 were $\geq 1 \%$ in relative abundance (Table S2). Proteobacteria, represented by Gamma-, Alpha- and Deltaproteobacteria classes, were dominant in all the analyzed samples (Fig. 3). Nevertheless, Bacteroidetes, Acidobacteria, Chloroflexi, Nitrospirae, Planctomycetes, Gemmatimonadetes and the NC10 phyla were also well represented in the samples. Two archaeal phyla, corresponding to the Euryarchaeota (Thermoplasmata class) and Crenarchaeota including Miscellaneous Crenarchaeota Group (MCG) and Thaumarchaeota classes (based on the GreenGene database), were also detected in low abundances (0.3 to $1.2 \%$ ) (Fig. 3). At lower taxonomic levels, 51 families were detected, from which Piscirickettsiaceae, Rhodobacteraceae, Flavobacteriaceae, Syntrophobacteraceae, Thermovibrionaceae, Desulfobacteraceae, Colwelliaceae, Marinicellaceae, Alcanivoracaceae, Colwelliaceae, and Cenarchaeaceae were among the families with higher relative abundances in the samples (Fig. S1A). Moreover, 23 genera were identified at $>1 \%$ of relative abundances (Fig S4). Desulfococcus, Alcanivorax, Fulvivirga, Amphritea, BD2-6, Shewanella, ZD0117 and Nitrospina were the better represented in the samples (Fig S4). 
234 Differential abundance analysis identified 147 OTUs with significant fold changes between the 235 deep and shallow zones, 107 from shallow and 40 from deep sites (Fig 4A). From the shallow 236 samples, most of these OTUs belonged to Delta-, Alpha- and Gammaproteobacteria (38, 24 and

237 18, respectively), while the rest of the OTUs were distributed in 13 classes of 10 phyla (Fig. 4A).

238 In deep samples, all of the 40 OTUs belonged to Gamma-, Alphaproteobacteria, Bacteroidetes 239 and Nitrospirae (27, 6, 6 and 1, respectively) (Fig 4A). The relative abundances of the 147 OTUs

240 with significant fold changes constituted approximately 10 to $40 \%$ of the total microbial

241 communities (Fig 4B). Kordiimonadales, Rhodospirillales, Desulfobacterales,

242 Syntrophobacterales and Nitrospirales, were the orders with highest relative abundances for

243 shallow samples whilst the orders Chromatiales, Oceanospirillales, Methylococcales,

244 Flavobacterialesand Rhodobacterales were the best represented orders for deep samples (Fig.

245 4B). At genus taxonomic level, differential abundance analysis allowed to identify Marinicella,

246 Alcanivorax, Shewanella and ZD0117 with significant fold changes for deep samples; and

247 Nitrosopumilus, GOUTA19, LCP-6, BD2-6, Amphritea, Desulfococcus and Mariprofundus for

248 shallow sites (Fig. S5).

249

250

\section{Discussion}

251

\section{Physicochemical properties of sediment samples}

252

253 Physicochemical properties (e.g., temperature, $\mathrm{pH}$, redox) in marine sediments commonly

254 change according to water depth (Miller et al. 2012). In this study, lime percentage, redox

255 potential and total sulfur were positively correlated to depth, while the clay particles percentages

256 were negatively correlated with depth (Table 1). The electronegative redox values measured in 
257 the first $5 \mathrm{~cm}$ of the sediments in all shallow sites (Table 1), suggested that oxygen was depleted

258 by microbial respiration as common reported for this layer in shallow marine sediments (Aranda 259 et al. 2015). Electronegative redox values in the shallow samples were likely enhanced at higher

260 fine-grained clay content, since this diminishes the sediment permeability as reported elsewhere

261 for sediments in the continental platform (Probandt et al. 2017). In contrast, the electropositive

262 redox values detected in the first $5 \mathrm{~cm}$ of the sediments in all the deep sites (Table 1) suggested

263 oxidizing conditions. This condition has also been observed at different latitudes in the GoM

264 (Deming and Carpenter 2008) due to both the circulation of deep water masses carrying oxygen

265 (Jochens and DiMarco 2008), and low rates of oxygen consumption (Rowe et al. 2008).

266

267

268

269

270

271

272

27

274

275

276

277

278

279

Total organic matter percentage (TOM $\%$ ) was determined to be below $2 \%$ for all the sediments analyzed (Table 1). These low organic contents are similar to those reported in studies of two onshore-offshore transects in the Northwestern GoM (Goñi et al. 1998). Shallow sites likely receive inputs from terrestrial organic matter (Balsam and Beeson 2003), and yet these sediments presented similar values of TOM than those detected for deep sites (Table 1). Previous studies have reported high production and consumption rates of oxygen measured for shallow sediments in Northeastern GoM (Mills et al. 2008). TOM values determined in this study for shallow sites are in concordance with previous reports for the GoM (Balsam and Beeson 2003). We hypothesize that these values are related to the consequence of high rates of microbial metabolism in those same zones."

\section{Microbial Ecology assessment}


280 The effect of storage temperature on microbial community structure has been previously studied,

281 and it is well recognized that microbial metabolism could keep on going at $-20^{\circ} \mathrm{C}$, however the

282 survival at these subzero temperatures requires several genetic and physiological strategies that

283 exclusively cold-adapted microorganisms (permafrost and seasonally frozen soil microbial

284 communities) have developed (Jansson and Tas 2014; Boetius et al 2015). In the present study,

285 microbial communities from marine sediments living at temperatures ranging from 4 to $27^{\circ} \mathrm{C}$

286 were analyzed. Thus, we considered that changes in the microbial community composition due

287 to the storage temperature $\left(-20^{\circ} \mathrm{C}\right)$ were unlikely, because the sediments were immediately

288 frozen at $-20^{\circ} \mathrm{C}$ on board and they were never thawed during the transport neither in the

289 laboratory before DNA extraction, as has been recommended in previous studies (Tedjo et al.

290 2015). The storage of the samples at $-20^{\circ} \mathrm{C}$ is a standard procedure commonly used for microbial

291 community analyses from marine sediment (e.g., Bienhold et al. 2016; Probandt et al. 2017).

293 Diversity indices are commonly used in microbial ecology studies to understand the links

294 between the environmental conditions and the community (Kimes et al. 2013; Bargiela et al. 295 2015). It has been suggested that microbial richness and diversity could be an expression of 296 environmental variation correlated to energy sources and temperature (Santelli et al. 2008;

297 Rosano-Hernández et al. 2012; Bargiela et al. 2015). Our results revealed higher richness and 298 diversity in shallow sites compared to deep sites (Table 2). This can be a result of more dynamic 299 shallow environments, characterized by strong physical mixing and seasonal variation. In 300 shallow environments the interaction among atmosphere, land and ocean increase environmental 301 variation, and therefore higher microbial diversity, as reported for coastal environments 302 elsewhere (Gobet et al. 2012). In contrast, lower richness and diversity in the deep sites could be 
303 the result of relatively constant environmental conditions. Microbes from the abyssal plains

304 environment are able to overcome the extreme conditions of temperature, pressure, oligotrophy

305 and darkness (Jochens and DiMarco 2008) but are subjected to far less environmental variability.

306

307 It is well recognized that marine sediments are dynamic environments shaped by interactions

308 among biotic and abiotic processes, including the redox reactions (Wasmund et al. 2017). In the

309 present study, the electronegative redox values detected in the first $5 \mathrm{~cm}$ of the sediments for

310 shallow sites (Table 1), suggested high microbial respiration or anoxic/reducing conditions

311 (Valdes and Real 2004; Aranda et al. 2015). However, genera known to be both aerobic (e.g.,

312 Marinicella and Nitrosopumilus) and anaerobic (e.g., Amphritea, Desulfococcus, GOUTA-19,

313 LCP-6, and Pseudidiomarina) were found in shallow samples (Fig S4). This suggested the co-

314 occurrence of different metabolisms in these sites, in accordance with previous reports for other

315 shallow marine sediments (Jørgensen 1977; Mills et al. 2008; Acosta-González et al. 2013; Tolar

316 et al. 2013; Cerqueira et al. 2015).

317

318 Electropositive redox values detected in the deep sites (Table 1), suggested oxidizing conditions

319 at those water depths, likely because the upper sediment layers remain oxygenated due to

320 relatively high oxygen concentrations in deep waters of the GoM (Jochens and DiMarco 2008) as

321 well as low rates of sediment community oxygen consumption previously reported in the deep

322 GoM (Rowe et al. 2008). In these oxidizing deep sediments, genera known to be aerobic and

323 facultative anaerobic bacteria, such as Shewanella, Alcanivorax, Marinicella, Nitrospina and

324 ZD0117 (Alteromonadaceae) were well represented (Fig. S4). Thus, these results suggest that 
325 aerobic (and facultatively anaerobic) lifestyles seem to be favored in abyssal sediments of the 326 studied region.

327

328 In this study, water depth was highly correlated with microbial community structure (Fig. 2). It is

329 known that water depth and its dependent variables, such as temperature and pressure, are among

330 the most important factors explaining variation in the bacterial community composition of

331 seafloor sediments (Orcutt et al. 2010; Bienhold et al. 2016). As an example of this, our results

332 showed a relatively high abundance of psychropiezophilic organisms of the genera Colwellia and

333 Shewanella for the deep sites (Fig. S2 and Fig. S4), where conditions are favorable for the

334 development of these microbial metabolisms (Nogi et al. 2004).

335

336 Detection of phylotypes putatively related to hydrocarbons degradation

337 Due to the presence of natural hydrocarbon effluents and the oil spills which have occurred in the

338 GoM (e.g., DWH spill), the potential effects of hydrocarbons on microbial community structure

339 has been extensively studied there (Rosano-Hernández et al. 2012; Orcutt et al. 2010;

340 Kleindienst et al. 2015). Recent investigations have provided insights about microbial

341 populations responding to the presence of hydrocarbons, highlighting microorganisms capable of

342 using these organic compounds as carbon source (Kostka et al. 2011; Redmond and Valentine

343 2011; Mason et al. 2012). In this work, we report the occurrence of several genera, such as

344 Shewanella, Alcanivorax, Pseudoalteromonas and Phaeobacter (Fig. S4), which have been

345 previously associated with hydrocarbon consumption (Beazley et al. 2012; Mason et al. 2014;

346 Barbato et al. 2016; Liu et al. 2017). 
348 In addition, this work reports for the first time NC10 and Kordiimonadales phylotypes for

349 sediments of the GoM (Fig. 3 and Fig S1), that based on the available information, are capable of

350 anaerobic methane oxidation with nitrite denitrification, and aerobic degradation of alkanes and

351 polycyclic aromatic hydrocarbons, respectively (Kwon et al. 2005; Xu et al. 2016; Math et al.

352 2012; Zhou and Xing 2015; Padilla et al. 2016). The Kordiimonadales phylotype was even

353 detected by DGGE band sequencing approach (Fig. S2B), supporting their relatively high

354 abundances in the analyzed samples.

355 The potential capability to degrade aromatic compounds, such as nitrotoluene, ethylbenzene,

356 chlorocyclohexane and fluorobenzoate were predicted based on trait modeling software

357 (PICRUSt) (Fig S3). This also suggests that microbial metabolisms related to the hydrocarbon

358 degradation might be well distributed in the Mexican region of the PFB and could contribute

359 with the bioremediation in case of hydrocarbon contamination due to forthcoming oil exploration

360 and extraction activities in this area.

361

\section{Conclusions}

363 To our knowledge, this is the first study to report differences in abundances and composition of

364 the microbial communities inhabiting surficial sediments in a water depth gradient in an

365 important province for oil extraction in the Mexican region of the Gulf of Mexico. In this study,

366 the combination of nucleic acid-based molecular methods and physicochemical measurements

367 allowed the detection of changes in the structures of microbial communities which were mainly

368 related to the redox potential, total sulfur concentration, grain size, as well as depth and the

369 variables that change with it, such as temperature and pressure. Our findings indicate that

370 shallow microbial communities are taxonomically richer than communities in the deep 
371 sediments. Bacterial phylotypes putatively related to hydrocarbon degradation appear to be well

372 represented for all the analyzed samples and could ameliorate future anthropogenic oil spills in

373 this region of the GoM. These results contribute to the current knowledge of the environmental

374 and biological dataset of the Perdido Fold Belt, which will be useful for further monitoring of

375 this area in the Gulf of Mexico.

376

377 Acknowledgements

378 We are thankful to David Valdes and Silvia Guadalupe Granados for providing the

379 physicochemical data; and to Abril Gamboa-Muñoz for the preparation of Fig. 1. Gregory

380 Arjona and Francisco Puc were responsible of the sampling during the oceanographic campaign.

381 We are very appreciative of many helpful discussions with Santiago Cadena and Alejandra

382 Escobar-Zepeda. The computational resources used for bioinformatics analyses at CINVESTAV-

383 Mérida were provided by Emanuel Hernández-Núñez.

384

385 References

386 Acosta-González A, Rosselló-Móra R, Marqués S (2013) Characterization of the anaerobic

387 microbial community in oil-polluted subtidal sediments: aromatic biodegradation potential

388 after the Prestige oil spill. Environ Microbiol 15:77-92. doi: 10.1111/j.1462-

$389 \quad 2920.2012 .02782 . x$

390

391 Aranda CP, Valenzuela C, Matamala Y, Godoy FA, Aranda N (2015) Sulphur-cycling

392 bacteria and ciliated protozoans in a Beggiatoaceae mat covering organically enriched

393 sediments beneath a salmon farm in a southern Chilean fjord. Mar Pollut Bull 100:270-278. 
395

396 Balsam WL and Beeson JP (2003) Sea-floor sediment distribution in the Gulf of Mexico,

397 Deep Sea Research Part I: Oceanographic Research Papers 50(12):1421-1444.

398

399 Barbato M, Scoma A, Mapelli F, De Smet R, Banat IM, Daffonchio D, Boon N, Borin S

400 (2016) Hydrocarbonoclastic Alcanivorax Isolates Exhibit Different Physiological and

401 Expression Responses to n-dodecane. Front Microbiol 7:1-14. doi:

$402 \quad 10.3389 /$ fmicb.2016.02056

403

404 Bargiela R, Mapelli F, Rojo D, Chouaia B, Tornés J, Borin S, Richter M, Del Pozo MV,

405 Cappello S, Gertler C, Genovese M, Denaro R, Martínez-Martínez M, Fodelianakis S, Amer

406 RA, Bigazzi D, Han X, Chen J, Chernikova TN, Golyshina OV, Mahjoubi M, Jaouanil A, 407 Benzha F, Magagnini M, Hussein E, Al-Horani F, Cherif A, Blaghen M, Abdel-Fattah YR, 408 Kalogerakis N, Barbas C, Malkawi HI, Golyshin PN, Yakimov MM, Daffonchio D, Ferrer M 409 (2015) Bacterial population and biodegradation potential in chronically crude oil-

410 contaminated marine sediments are strongly linked to temperature. Nat Sci Reports 5:11651.

411 doi: $10.1038 /$ srep11651

412

413 Beazley MJ, Martinez RJ, Rajan S, Powell J, Piceno YM, Lauren MT, Andersen GL, Hazen

414 TC, Van Nostrand JD, Zhou J, Mortazavi B, Sobecky PA (2012) Microbial Community

415 analysis of a coastal salt marsh affected by the Deepwater Horizon oil spill. PLoS One

416 7:e41305. doi: 10.1371/journal.pone.0041305 
418 Benjamini Y, Hochberg Y (1995) Controlling the false discovery rate: A practical and 419 powerful approach to multiple testing. J RStatSoc. 57:289-300.

420

421 Bienhold C, Zinger L, Boetius A, Ramette A (2016) Diversity and biogeography of bathyal 422 and abyssal seafloor bacteria. PLoS One 1-20. doi: 10.1371/journal.pone.0148016

423

424 Boetius A, Anesio AM, Deming JW, Mikucki JA, Rapp JZ (2015) Microbial ecology of the 425 cryosphere: Sea ice and glacial habitats. Nat Rev Microbiol 13:677-690. doi:

$426 \quad 10.1038 /$ nrmicro3522

427

428 Brassard P (1997) Measurement of Eh and $\mathrm{pH}$ in aquatic sediments, in Manual of 429 physicochemical analysis of aquatic sediments, edited by A Mudroch, J M Azcue\& P 430 Mudroch (CRC Press, Inc. Lewis Publishers), pp. 47-69.

431

432 Bricker OP (1982) Redox potential: Its measurement and importance in water systems, in:

433 Water analysis, Vol 1, Inorganic species, edited by R AMinear\& L H Keith, (Academic Press 434 Inc, Florida, USA), pp. 55-79.

435

436 Buchanan JB (1984) Sediment analysis. In: Holme, N. A. \&Mcintyre, A.D. (Eds.) Methods

437 for the study of marine benthos. Second Edition. Second Edition. \& 3:41-65. Blackwell 438 Scientific Publications. Oxford. 
440 Caporaso JG, Kuczynski J, Stombaugh J, Bittinger K, Bushman FD, Costello EK, Noah F, 441 Gonzalez Peña A, Goodrich JK, Gordon JI, Huttley GA, Kelley AT, Knights D, Koenig JE, 442 Ley RE, Lozupone CA, McDonald D, Muegge BD, Pirrung M, Reeder J, Sevinsky JR, 443 Turnbaugh PJ, Walters WA, Widmann J, Yatsunenko T, Zaneveld J, Knight R (2010) QIIME 444 allows analysis of high-throughput community sequencing data. Nature methods 7(5):335. 445

446 Cerqueira T, Pinho D, Egas C, Froufe, H, Altermark B, Candeias C, Santos RS, Bettencourt 447 R (2015) Microbial diversity in deep-sea sediments from the Menez Gwen hydrothermal vent 448 system of the Mid-Atlantic Ridge. Mar Genomics 24:343-355. doi:

$449 \quad$ 10.1016/j.margen.2015.09.001

450

451 Deming JW, Carpenter SD (2008) Factors influencing benthic bacterial abundance, biomass, 452 and activity on the northern continental margin and deep basin of the Gulf of Mexico. Deep 453 Sea Res Part II 55:2597-2606. doi: 10.1016/j.dsr2.2008.07.009

454

455 Edgar RC (2010) Search and clustering orders of magnitude faster than BLAST.

456 Bioinformatics 26:2460-2461. doi: 10.1093/bioinformatics/btq461

457

458 Edgar RC (2016). UCHIME2: improved chimera prediction for amplicon sequencing. 459 bioRxiv. doi: doi: http://dx.doi.org/10.1101/074252

460

461 Fuhrman JA, Cram JA, Needham DM (2015) Marine microbial community dynamics and 462 their ecological interpretation. Nat Microbiol Rev 13:133-146. doi: 10.1038/nrmicro3417 
463

464 Giloteaux L, Goñi-Urriza M, Duran R (2010) Nested PCR and new primers for analysis of 465 sulfate-reducing bacteria in low-cell-biomass environments. Appl Environ Microbiol

466 76:2856-2865. doi: 10.1128/AEM.02023-09

467

468 Gobet A, Böer SI, Huse SM, van Beusekom JEE, Quince C, Sogin ML, Boetius A, Ramette 469 A (2012) Diversity and dynamics of rare and of resident bacterial populations in coastal $470 \quad$ sands. 542-553. doi: 10.1038/ismej.2011.132

471

472 Goñi MA, Ruttenberg KC, Eglinton TI (1998) A reassessment of the sources and importance 473 of land-derived organic matter in surface sediments from the Gulf of Mexico.

474 GeochimCosmochim Acta 62:3055-3075. doi: Doi 10.1016/S0016-7037(98)00217-8

475

476 Huber JA, Welch DBM, Morrison HG, Huse SM, Neal PR, Butterfield DA, Sogin ML 477 (2007) Microbial population structures in the Deep Marine Biosphere. Science (80- ) 318:97$478 \quad 101$.

479

480 Illumina (2014) MiSeq Reporter Metagenomics Workflow Reference Guide. 5 pp.

481 Jiang H, Dong H, Ji S, Ye Y, Wu N (2007) Microbial diversity in the deep marine sediments

482 from the Qiongdongnan Basin in South China Sea. Geomicrobiol J 0451:505. doi:

$483 \quad 10.1080 / 01490450701572473$

484

485 Jansson JK and Tas N (2014) The microbial ecology of permafrost. Nature Reviews 
486 Microbiology volume 12, pages 414-425

487

488 Jochens AE, DiMarco SF (2008) Physical oceanographic conditions in the deep-water Gulf 489 of Mexico in summer 2000-2002. Deep Res Part II Top Stud Oceanogr 55:2541-2554. doi: $490 \quad$ 10.1016/j.dsr2.2008.07.003

491

492 Jones SE, Cadkin TA, Newton RJ, McMahon KD (2012) Spatial and temporal scales of 493 aquatic bacterial beta diversity. Front Microbiol 3:1-10. doi: 10.3389/fmicb.2012.00318 494

495 Jørgensen BB (1977) Bacterial sulfate reduction within reduced microniches of oxidized 496 marine Sediments. 17:7-17.

497

498 Joye SB, Teske AP, Kostka JE (2014) Microbial dynamics following the Macondo oil well 499 blowout across Gulf of Mexico environments. Bioscience 64:766-777. doi:

$500 \quad 10.1093 /$ biosci/biu121

501

$502 \quad$ Katoh K, Standley DM (2013) MAFFT multiple sequence alignment software version 7:

503 Improvements in performance and usability. MolBiolEvol 30:772-780. doi:

$504 \quad 10.1093 / \mathrm{molbev} / \mathrm{mst} 010$

505

506 Kimes NE, Callaghan AV, Aktas DF, L, Smith WL, Sunner J Golding BT, Drozdowska M, 507 Hazen TC, Suflita JM, Morris PJ (2013) Metagenomic analysis and metabolite profiling of 508 deep-sea sediments from the Gulf of Mexico following the Deepwater Horizon oil spill. 
509 Front Microbiol 4:1-17. doi: 10.3389/fmicb.2013.00050

510

511 King GM, Smith CB, Tolar B, Hollibaugh JT (2013) Analysis of composition and structure

512 of coastal to mesopelagic bacterioplankton communities in the northern Gulf of Mexico.

$513 \quad$ Front Microbiol 3:1-14. doi: 10.3389/fmicb.2012.00438

514

515 Kleindienst S, Grim S, Sogin M, Bracco A, Crespo-Medina M, Joye SB (2015) Diverse, rare 516 microbial taxa responded to the Deepwater Horizon deep-sea hydrocarbon plume. ISME J

517 10:1-16. doi: 10.1038/ismej.2015.121

518

519 Klindworth A, Pruesse E, Schweer T, Peplies J, Quast C, Horn M, Glöcker FO (2013)

520 Evaluation of general 16S ribosomal RNA gene PCR primers for classical and next-

521 generation sequencing-based diversity studies. Nucleic Acids Research 41:1-11. doi:

$522 \quad 10.1093 /$ nar/gks808

523

524 Kopylova E, Noé L, Touzet H (2012) SortMeRNA: fast and accurate filtering of ribosomal 525 RNAs in metatranscriptomic data. Bioinformatics 28:3211-3217. doi:

$526 \quad 10.1093 /$ bioinformatics/bts611

527

528 Kostka JE, Prakash O, Overholt WA, Green SJ, Freyer G, Canion A, Delgardio J, Norton N, 529 Hazen TC, Huettel M (2011) Hydrocarbon-degrading bacteria and the bacterial community 530 response in Gulf of Mexico beach sands impacted by the Deepwater Horizon oil spill. Appl 531 Environ Microbiol 77:7962-7974. doi: 10.1128/AEM.05402-11 
532

533 Kwon KK, Lee H-S, Yang SH, Kim S-J (2005) Kordiimonas gwangyangensis gen. nov., sp.

534 nov., a marine bacterium isolated from marine sediments that forms a distinct phyletic

535 lineage (Kordiimonadales ord. nov.) in the "Alphaproteobacteria". Int J SystEvolMicrobiol 536 55:2033-2037. doi: 10.1099/ijs.0.63684-0

537

538 Liu Z, Liu J (2013) Evaluating bacterial community structures in oil collected from the sea 539 surface and sediment in the northern Gulf of Mexico after the Deepwater Horizon oil spill.

$540 \quad$ MicrobiologyOpen 2:492-504. doi: 10.1002/mbo3.89

541

542 Liu J, Bacosa HP, Liu Z (2017) Potential environmental factors affecting oil-degrading 543 bacterial populations in deep and surface waters of the Northern Gulf of Mexico. Front

$544 \quad$ Microbiol 7:1-14. doi: 10.3389/fmicb.2016.02131

545

546 Love MI, Huber W, Anders S (2014). Moderated estimation of fold change and dispersion

547 for RNA-seq data with DESeq2. Genome Biol 15:1-21. doi: 10.1186/s13059-014-0550-8

548

549 Lozupone C, Hamady M, Knight R (2006) UniFrac-an online tool for comparing microbial 550 community diversity in a phylogenetic context. BMC Bioinformatics 7:371. doi:

$551 \quad 10.1186 / 1471-2105-7-371$

552

553 Magoč T, SL Salzberg (2011) FLASH: fast length adjustment of long reads to improve 554 genome assemblies. Bioinformatics 27:2957-2963. doi: 10.1093/bioinformatics/btr507 
555

556 Mason OU, Hazen TC, Borglin S, Chain PSG, Dubinsky EA, Fortney JL, Han J, Holman H-

557 YN, Hultman J, Tringe SG, Woyke T, Zhou J, Rubin, Jansson JK EM (2012) Metagenome,

558 metatranscriptome and single-cell sequencing reveal microbial response to Deepwater

559 Horizon oil spill. ISME J 6:1715-27. doi: 10.1038/ismej.2012.59

560

561 Mason OU, Han J, Woyke T, Jansson JK (2014) Single-cell genomics reveals features of a

562 Colwellia species that was dominant during the Deepwater Horizon oil spill ASSEMBLY.

$563 \quad 5: 1-8$. doi: $10.3389 /$ fmicb. 2014.00332

564

565 Math RK, Jeong SH, Jin HM, Park MS, Kim JM, Jeon CO (2012) Kordiimonasaestuarii sp. 566 nov., a marine bacterium isolated from a tidal flat. Int J SystEvolMicrobiol 62:3049-3054.

567 doi: $10.1099 /$ ijs.0.038943-0

568

569 McMurdie PJ, Holmes S (2013) phyloseq: An R package for reproducible interactive

570 analysis and graphics of microbiome census data. PLoS One. doi:

$571 \quad$ 10.1371/journal.pone.0061217

572

573 Miller CB, Wheeler PA (2012) The fauna in deep-sea sediments In Miller CB, Wheeler PA 574 (Eds.) Biological oceanography (pp 292-320). Wiley-Blackwell 474p

575

576 Mills HJ, Hunter E, Humphrys M, Kerkhof L, McGuinness L, Huettel M, Kostka JE (2008)

577 Characterization of nitrifying, denitrifying, and overall bacterial communities in permeable 
578 marine sediments of the Northeastern Gulf of Mexico. Appl Environ Microbiol 74:4440-

579 4453. doi: 10.1128/AEM.02692-07

580

581 Mills HJ, Martinez RJ, Story S, Sobecky PA (2004) Identification of members of the

582 metabolically active microbial populations associated with Beggiatoa species mat

583 communities from Gulf of Mexico cold-seep sediments. Society 70:5447-5458. doi:

$584 \quad 10.1128 /$ AEM.70.9.5447

585

586 Nogi Y, Hosoya S, Kato C, Horikoshi K (2004) Colwelliapiezophila sp. nov., a novel

587 piezophilic species from deep-sea sediments of the Japan Trench. Int J SystEvolMicrobiol

588 54:1627-1631. doi: 10.1099/ijs.0.03049-0

589

590 Oksanen, J 2013. Multivariate analysis of ecological communities in R: vegan tutorial. 3:121

591

592 Orcutt BN, Joye SB, Kleindienst S, Knittel K, Ramette A, Reitz A, Samarkin V, Treude T, 593 Boetius A (2010) Impact of natural oil and higher hydrocarbons on microbial diversity, 594 distribution, and activity in Gulf of Mexico cold-seep sediments. Deep-Sea Research II $595 \quad$ 57:2008-2021. doi: 10.1016/j.dsr2.2010.05.014

596

597 Padilla CC, Bristow LA, Sarode N, Garcia-Robledo E, Gómez E, Benson CR, Bourbonnais 598 A, Altabet MA, Girguis PR, Thamdrup B, Stewart FJ (2016) NC10 bacteria in marine oxygen 599 minimum zones. ISME J 10:2067-2071. doi: 10.1038/ismej.2015.262

600 
601 Price MN, Dehal PS, Arkin AP (2009) Fasttree: Computing large minimum evolution trees

602 with profiles instead of a distance matrix. MolBiolEvol 26:1641-1650. doi:

$603 \quad 10.1093 / \mathrm{molbev} / \mathrm{msp} 077$

604

605 Probandt D, Knittel K, Tegetmeyer HE, Ahmerkamp S, Holtappels, Amann R (2017)

606 Permeability shapes bacterial communities in sublittoral surface sediments. Environ

607 Microbiol 19:1584-1599. doi: 10.1111/1462-2920.13676

608

609 R Core Team (2014). R: A language and environment for statistical computing. R

610 Foundation for Statistical Computing, Vienna, Austria. URLhttp://www.R-project.org/.

611

612 Redmond MC, Valentine DL (2011) Natural gas and temperature structured a microbial

613 community response to the Deepwater Horizon oil spill. doi: 10.1073/pnas.1108756108/-

614 /DCSupplemental.www.pnas.org/cgi/doi/10.1073/pnas.1108756108

615

616 Reese BK, Mills HJ, Dowd SE, Morsee JW (2013) Linking molecular microbial ecology to 617 geochemistry in a coastal hypoxic zone. Geomicrobiol J 0451:160-172. doi:

$618 \quad 10.1080 / 01490451.2012 .659331$

619

620 Rosano-Hernández MC, Ramírez-Saad H, Fernández-Linares L (2012) Petroleum influenced 621 beach sediments of the Campeche Bank, Mexico: diversity and bacterial community structure 622 assessment. J Environ Manage 95:S325-S331. doi: 10.1016/j.jenvman.2011.06.046

623 
624 Rowe GT, Morse J, Nunnally C, Boland GS (2008) Sediment community oxygen

625 consumption in the deep Gulf of Mexico. Deep Res Part II 55:2686-2691. doi:

$626 \quad 10.1016 / \mathrm{j} . \mathrm{dsr} 2.2008 .07 .018$

627

628 Salcedo DL, Soto LA, Estradas-Romero A, Botello A V (2017) Interannual variability of 629 soft-bottom macrobenthic communities of the NW Gulf of Mexico in relationship to the 630 Deepwater Horizon oil spill. Mar Pollut Bull 114:987-994. doi:

$631 \quad$ 10.1016/j.marpolbul.2016.11.031

632

633 Santelli CM, Orcutt BN, Banning E, Bach W, Moyer CL, Sogin ML, Staudigel H, Edwards 634 KJ (2008) Abundance and diversity of microbial life in ocean crust. Nat Lett 453:653-656. 635 doi: $10.1038 /$ nature06899

636

637 Santos HF, Carmo FL, Paes JES, Rosado AS, Peixoto RS (2011) Bioremediation of

638 mangroves impacted by Petroleum. Water Air Soil Pollut 216:329-350. doi:

$639 \quad 10.1007 / \mathrm{s} 11270-010-0536-4$

640

641 Soto LA, Vázquez-Botello A (2013) Legal issues and scientific constraints in the

642 environmental assessment of the Deepwater Horizon oil spill in Mexico Exclusive Economic 643 Zone (EEZ) in the Gulf of Mexico. Int J Geosci 4:39-45.

644

645 Tedjo DI, Jonkers DMAE, Savelkoul PH, Masclee AA, van Best N, Pierik MJ, Penders J

646 (2015) The Effect of Sampling and Storage on the Fecal Microbiota Composition in Healthy 
647 and Diseased Subjects. PLoS ONE 10(5): e0126685.

$648 \quad$ https://doi.org/10.1371/journal.pone.0126685

649

650 Tolar BB, King GM, Hollibaugh JT (2013) An analysis of Thaumarchaeota populations from

651 the northern Gulf of Mexico. Front Microbiol 4:1-36. doi: 10.3389/fmicb.2013.00072

652

653 Valdes DS, Real E (2004) Nitrogen and phosphorus in water and sediments at Ria Lagartos

654 coastal lagoon, Yucatan, Gulf of Mexico. Indian J Mar Sci 33:338-345.

655

656 Wasmund K, Mußmann M, Loy A (2017) The life sulfuric: microbial ecology of sulfur 657 cycling in marine sediments. Environ Microbiol Rep 9:323-344. doi: 10.1111/1758-

$658 \quad 2229.12538$

659

660 Webster G, Newberry CJ, Fry JC, Weightman AJ (2003) Assessment of bacterial community

661 structure in the deep sub-seafloor biosphere by 16S rDNA-based techniques: a cautionary

662 tale. J Microbiol Methods 55:155-164. doi: 10.1016/S0167-7012(03)00140-4

663

664 Wickham, H. (2010). ggplot2: Elegant graphics for data analysis. J Stat Sortw July 35:1-3.

665

666 Xu X-W, Huo Y-Y, Bai X-D, Bai X-D, Wang C-S, Oren A, Li A-Y, Wu M (2011)

667 Kordiimonaslacus sp. nov., isolated from a ballast water tank, and emended description of

668 the genus Kordiimonas. Int J SystEvolMicrobiol 61:422-6. doi: 10.1099/ijs.0.018200-0

669 
670 Zhou J, Xing J (2015) Effect of electron donors on the performance of haloalkaliphilic

671 sulfate-reducing bioreactors for flue gas treatment and microbial degradation patterns related

672 to sulfate reduction of different electron donors. BiochemEng J 96:14-22. doi:

$673 \quad 10.1016 / j \cdot b e j .2014 .12 .015$ 


\section{Figure 1}

Location of sampling sites in the Mexican Region of the Northwestern Gulf of Mexico.

Circles: shallow sites in the continental platform and slope from 20 to $600 \mathrm{~m}$ depth.

Triangles: deep sites in the abyssal plain from 2800 to $3700 \mathrm{~m}$ depth. The names of the stations are indicated. Source credit: Abril Gamboa-Muñoz.

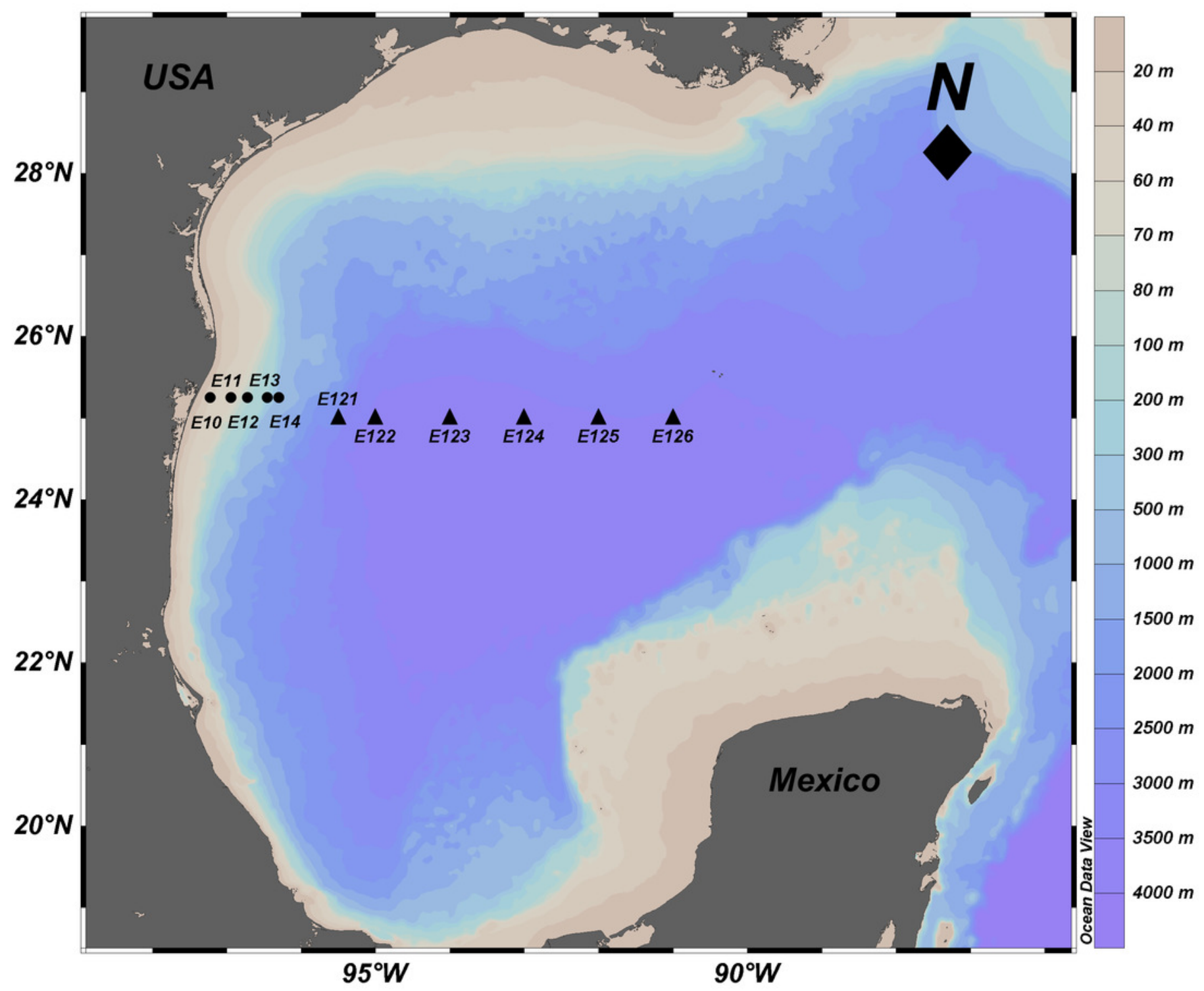


Figure 2

Non-metric multidimensional scaling (NMDS) of the bacterial community structure and the environmental variables.

Ordination of samples based on the weighted UniFrac distance from the community structure and their relationship with the physicochemical variables. Shallow sites included samples collected from 20 to $600 \mathrm{~m}$, and deep sites from 2800 to $3700 \mathrm{~m}$ depth. Physicochemical variables related to the bacterial community structure are shown in green arrows. TS total sulfur concentration. NMDS stress value $=0.0684$.

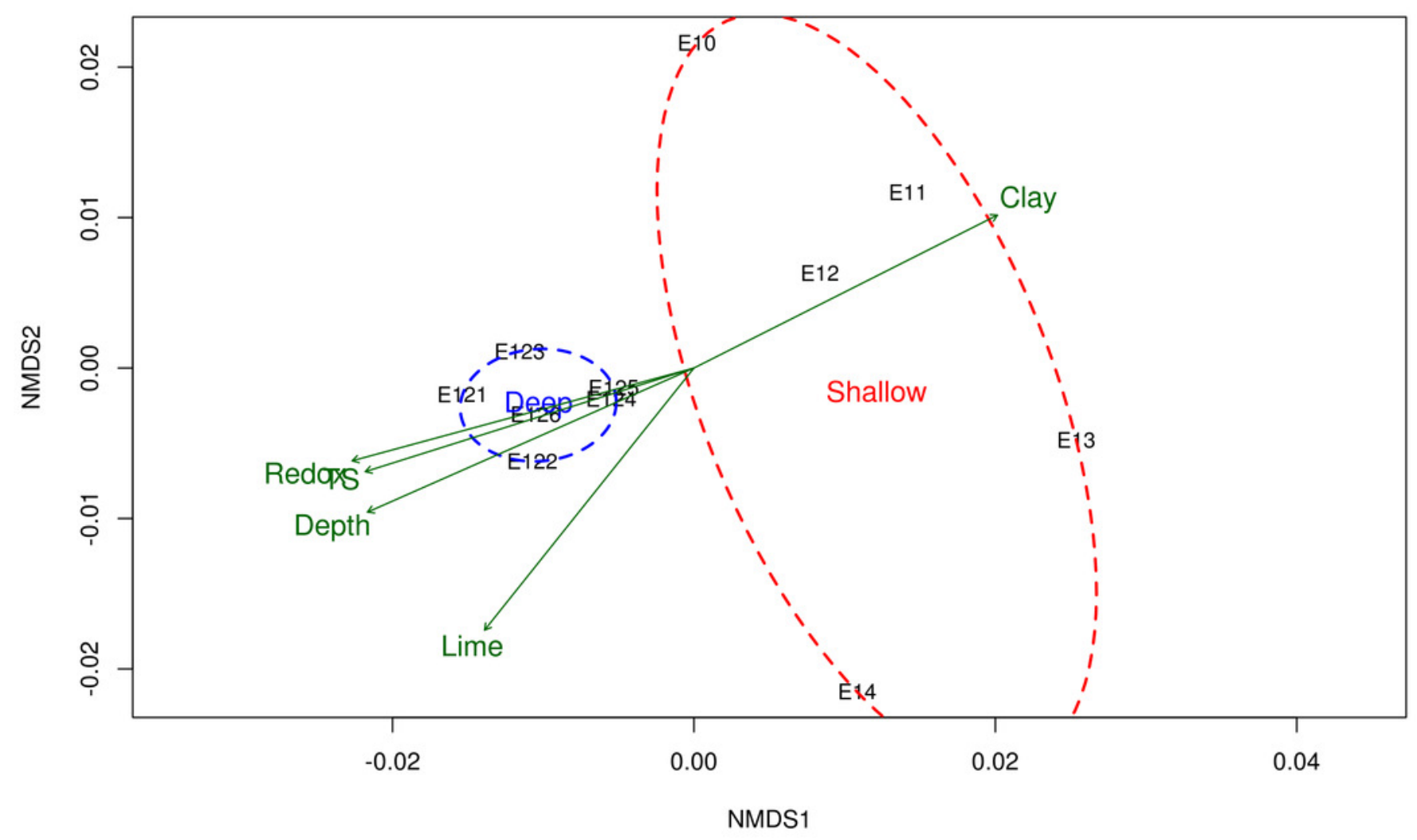




\section{Figure 3}

Relative abundances from bacteria inhabiting sediments in the Mexican Region in the northwestern GM.

Taxonomic diversity at phylum and class levels from shallow and deep samples. Shallow sediment samples retrieved from 20 to $600 \mathrm{~m}$ depth, and deep sediment samples retrieved from 2800 to $3700 \mathrm{~m}$ depth. Only the 20 most abundant classes are shown. The remaining classes were agglomerated in the "Others" category.

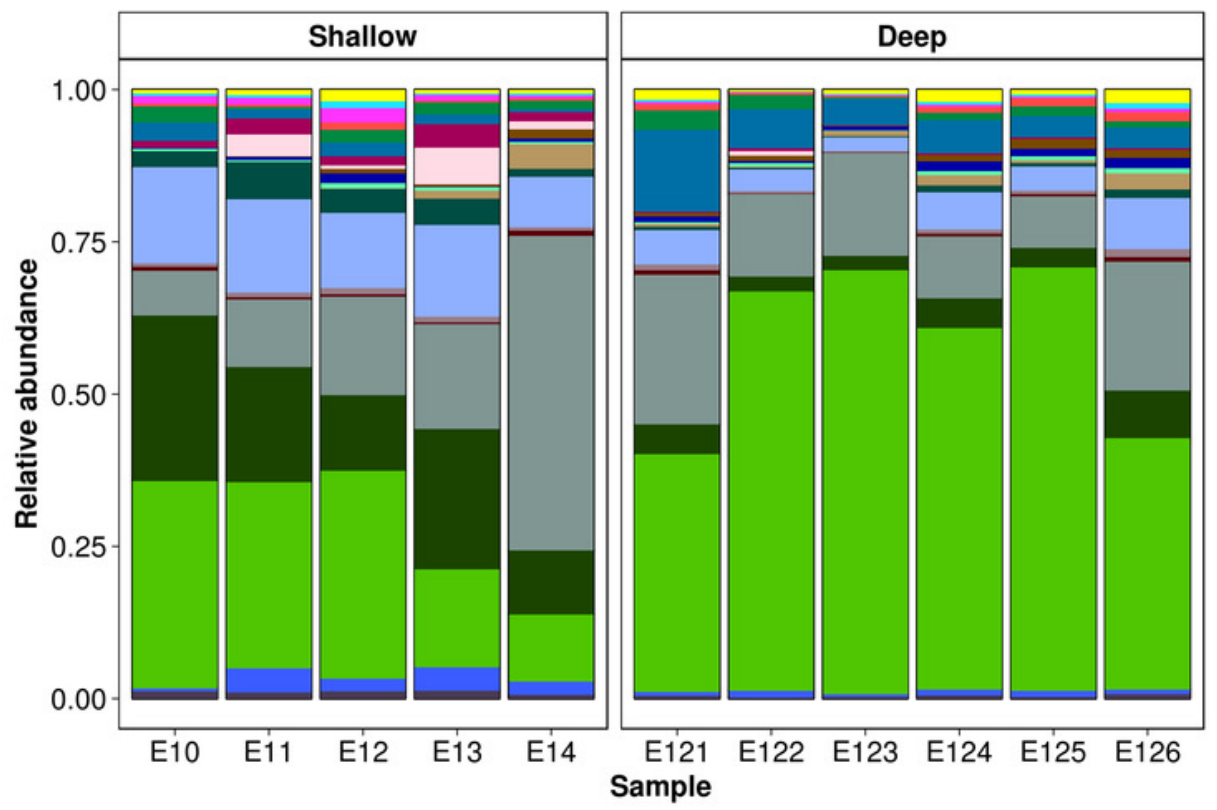

Phylum Class

Acidobacteria BPC102

Acidobacteria RB25

Acidobacteria Sva0725

Actinobacteria Acidimicrobiia

Bacteroidetes Cytophagia

Bacteroidetes Flavobacteriia

Chloroflexi Anaerolineae

Chloroflexi Dehalococcoidetes

Chloroflexi SAR202

Crenarchaeota Thaumarchaeota

Gemmatimonadetes Gemm-1

NC10 wb1-A12

Nitrospirae Nitrospira

Others

Planctomycetes Phycisphaerae

Planctomycetes Planctomycetia

Proteobacteria Alphaproteobacteria

Proteobacteria Deltaproteobacteria

Proteobacteria Gammaproteobacteria

Unassigned

WS3 PRR-12 
Figure 4

Differential OTUs abundance among shallow and deep communities from sediment samples in the Mexican northwestern Gulf of Mexico.

A) OTUs with significant fold changes among the community composition from shallow and deep zones. Circles in colors defines the phyla of the OTUs. B) Relative abundances of the OTUs with significant fold changes at a class-order taxonomic level.
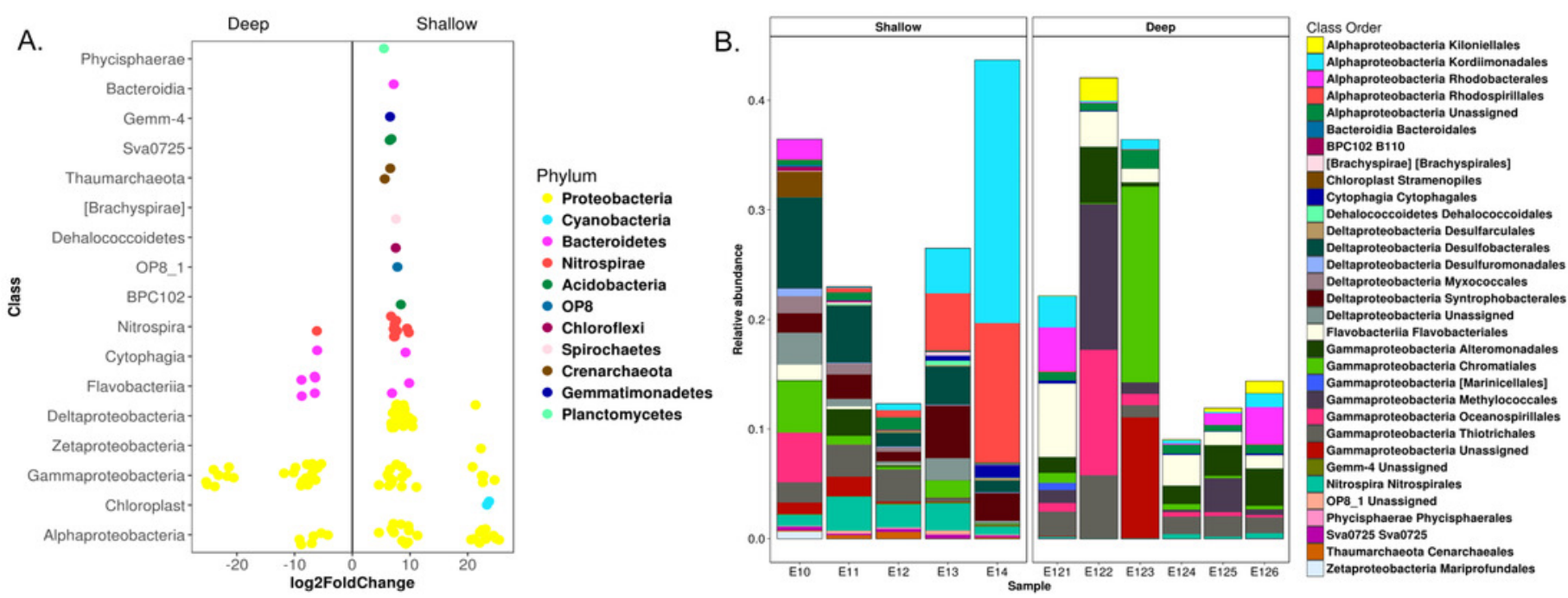


\section{Table $\mathbf{1}$ (on next page)}

Physicochemical variables from shallow and deep sediment samples.

TS total sulfur, TOM total organic matter and TOC total organic carbon. Physicochemical variables measured with no replicates. Pearson coefficient showed significant correlation at a $p$-value $<0.01$ among TS $\left(r^{2}=0.98\right)$, redox potential $\left(r^{2}=0.98\right)$, and the percentages of lime $\left(r^{2}=0.78\right)$ and clay $\left(r^{2}=-0.78\right)$ particles with depth. $\uparrow$ Variables with positive correlation with depth. $\downarrow$ Variables with negative correlation with depth. 
1 Table 1. Physicochemical variables from shallow and deep sediment samples.

\section{Geographical location Physicochemical variables}

\begin{tabular}{|c|c|c|c|c|c|c|c|c|c|c|c|}
\hline Site & $\begin{array}{r}\text { Sam } \\
\text { ple }\end{array}$ & Longitude & Latitude & $\begin{array}{c}\text { Depth } \\
\text { (m) }\end{array}$ & $\begin{array}{c}\text { Redox } \uparrow \\
\text { (mV) }\end{array}$ & $\begin{array}{l}\text { TS 个 } \\
(\mu \mathrm{M})\end{array}$ & $\begin{array}{l}\text { TOM } \\
(\%)\end{array}$ & $\begin{array}{l}\text { TOC } \\
(\mu \mathrm{M})\end{array}$ & $\begin{array}{l}\text { Sand } \\
(\%)\end{array}$ & $\begin{array}{c}\text { Lime } \uparrow \\
(\%)\end{array}$ & $\begin{array}{c}\text { Clay } \downarrow \\
(\%)\end{array}$ \\
\hline \multirow{5}{*}{ Shallow } & E10 & $97^{0} 13^{\prime} 48^{\prime \prime} \mathrm{W}$ & $25^{0} 15^{\prime} \mathrm{N}$ & 20 & -131.0 & 0.05 & 0.80 & 0.45 & 34.5 & 51.2 & 14.4 \\
\hline & E11 & $96^{0} 56^{\prime} 24^{\prime \prime} \mathrm{W}$ & $25^{0} 15^{\prime} \mathrm{N}$ & 75 & -174.4 & 0.05 & 1.10 & 0.61 & 26.5 & 57.3 & 16.3 \\
\hline & E12 & $96^{0} 43^{\prime} 12^{\prime \prime} \mathrm{W}$ & $25^{0} 15^{\prime} \mathrm{N}$ & 100 & -204.0 & 0.05 & 1.02 & 0.56 & 20.5 & 51.2 & 28.4 \\
\hline & E13 & $96^{0} 27^{\prime} 36^{\prime \prime} \mathrm{W}$ & $25^{0} 15^{\prime} \mathrm{N}$ & 200 & -131.7 & 0.05 & 0.83 & 0.46 & 22.5 & 51.2 & 26.4 \\
\hline & E14 & $96^{0} 18^{\prime} 36^{\prime \prime} \mathrm{W}$ & $25^{0} 15^{\prime} \mathrm{N}$ & 600 & -192.9 & 0.05 & 1.02 & 0.56 & 23.7 & 68.2 & 8.1 \\
\hline \multirow{6}{*}{ Deep } & E121 & $95^{0} 30^{\prime} \mathrm{W}$ & $25^{\circ} 00^{\prime} \mathrm{N}$ & 2800 & 230 & 0.10 & 1.22 & 0.68 & 33.75 & 60.3 & 6.0 \\
\hline & E122 & $95^{\circ} 00^{\prime} \mathrm{W}$ & $25^{\circ} 00^{\prime} \mathrm{N}$ & 3600 & 233 & 0.10 & 0.59 & 0.33 & 27.75 & 66.3 & 6.0 \\
\hline & E123 & $94^{0} 00^{\prime} \mathrm{W}$ & $25^{\circ} 00^{\prime} \mathrm{N}$ & 3700 & 225 & 0.11 & 0.44 & 0.25 & 25.7 & 66.3 & 8.0 \\
\hline & E124 & $93^{\circ} 00^{\prime} \mathrm{W}$ & $25^{\circ} 00^{\prime} \mathrm{N}$ & 3700 & 215 & 0.11 & 0.85 & 0.47 & 29.8 & 64.3 & 5.9 \\
\hline & E125 & $92^{0} 00^{\prime} \mathrm{W}$ & $25^{\circ} 00^{\prime} \mathrm{N}$ & 3500 & 236 & 0.12 & 0.81 & 0.45 & 23.9 & 70.3 & 5.9 \\
\hline & E126 & $91^{\circ} 00^{\prime} \mathrm{W}$ & $25^{\circ} 00^{\prime} \mathrm{N}$ & 3700 & 215 & 0.12 & 0.92 & 0.51 & 25.8 & 68.2 & 6.0 \\
\hline
\end{tabular}

2 TS total sulfur, TOM total organic matter and TOC total organic carbon. Physicochemical variables

3 measured with no replicates. Pearson coefficient showed significant correlation at a $p$-value $<0.01$ among

4 TS $\left(r^{2}=0.98\right)$, redox potential $\left(r^{2}=0.98\right)$, and the percentages of lime $\left(r^{2}=0.78\right)$ and clay $\left(r^{2}=-0.78\right)$

5 particles with depth.

$6 \uparrow$ Variables with positive correlation with depth.

$7 \downarrow$ Variables with negative correlation with depth.

8 


\section{Table 2 (on next page)}

Alpha diversity estimations

Alfa diversity data from observed OTUs, $H^{\prime}$ Shannon diversity index, $D$ Simpson diversity index, and Chaol for nonparametric richness estimation. Statistical differences were observed among sampling sites Shallow and Deep-sea ( $p$-value $<0.05)$. Percentages of Good`s coverage shows the fraction of the OTUs subsampled more than once. 
Table 2. Alpha diversity estimations.

\begin{tabular}{|c|c|c|c|c|c|c|c|c|}
\hline \multirow[b]{2}{*}{ Site } & \multirow[b]{2}{*}{ Sample } & \multirow[b]{2}{*}{$\begin{array}{c}\text { Depth } \\
\text { (m) }\end{array}$} & \multirow[b]{2}{*}{$\begin{array}{l}\text { Total } \\
\text { counts }\end{array}$} & \multirow[b]{2}{*}{$\begin{array}{l}\text { Observe } \\
\text { d OTUs }\end{array}$} & \multicolumn{3}{|c|}{ Ecological estimators } & \multirow[b]{2}{*}{$\begin{array}{c}\text { Good's } \\
\text { coverage } \\
(\%)\end{array}$} \\
\hline & & & & & $\boldsymbol{H}^{\prime}$ & $D$ & Chao1 & \\
\hline \multirow{5}{*}{ Shallow } & E10 & 20 & 48886 & 2401 & 9.3 & 0.99 & 3002.2 & 96.51 \\
\hline & E11 & 75 & 30290 & 3262 & 10.1 & 1.00 & 4141.4 & 94.83 \\
\hline & E12 & 100 & 21243 & 3509 & 10.4 & 1.00 & 4770.5 & 93.94 \\
\hline & E13 & 200 & 35253 & 3081 & 9.8 & 1.00 & 3925.3 & 95.09 \\
\hline & E14 & 600 & 42131 & 2188 & 8.2 & 0.99 & 3116.4 & 95.8 \\
\hline \multirow{6}{*}{ Deep } & E121 & 2800 & 53408 & 2238 & 8.7 & 0.99 & 3087.3 & 95.75 \\
\hline & E125 & 3600 & 56735 & 1434 & 7.0 & 0.97 & 2059.0 & 97.36 \\
\hline & E122 & 3700 & 20402 & 1243 & 6.7 & 0.97 & 2081.6 & 97.23 \\
\hline & E123 & 3700 & 61025 & 2139 & 8.0 & 0.97 & 3181.1 & 95.54 \\
\hline & E124 & 3500 & 42768 & 1848 & 6.9 & 0.94 & 3009.7 & 95.80 \\
\hline & E126 & 3700 & 45107 & 2406 & 9.11 & 0.99 & 3418.39 & 95.40 \\
\hline
\end{tabular}

Alfa diversity data from observed OTUs, $H^{\prime}$ Shannon diversity index, $D$ Simpson diversity index, and Chao1for nonparametric richness estimation. Statistical differences were observed among sampling sites Shallow and Deep-sea ( $p$-value $<0.05)$. Percentages of Good's coverage shows the fraction of the OTUs subsampled more than once. 